\title{
ヒナの体脂肪蓄積におよぼす飼料蛋白質の影響の週路 および鷄種間の差
}

\author{
重野嘉吉・星井 博*.吉田 奏*

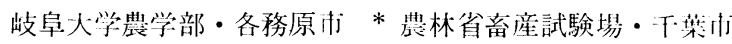

鵎ヒナに対寸る飼料組成の影響については，古くは， FRAPS $^{1)}$ が体成分と飼料中の蛋白質，脂肪およびェネル ギーの関係を報告して以来, 極めて多くの研究が行わ机 て来た。飼料の增体率, 飼料効率を向上させるために, エネルギーを高くするS ScotT et al. ${ }^{2)}$ の報告をはじめと して, 主としてェネルギーレバルの変化を中心とした研 究で，体脂肪率への影響も検刢された ${ }^{3,4,5)}$ 。DoNALDSON et $a l .{ }^{6)}$ のエネルギーを一定にして蛋白質レベルをあげ ると, 体脂肪率が低下するという報告に前後して, 力口 リーと蛋白質の比率の効果の研究上体脂肪率の增減が検 討されるようになった。それらの報告7 11) 一の増減に研究の重点が抢かれていた。体脂肪率に対子 る蛋白質の影響は, DonALDSON et al. ${ }^{61}$ を初めとして, 多く0報告12 20) が発表され，蛋白質含量を增すことによ って，体脂肪率が低下する現象が明らかにされて来た。

Yoshida and Morimoto ${ }^{21,22)}$ は初生ヒナの体脂肪含量 は, 飼料組成によって容易に, しかも可逆的に变化する ことを明らかにし，飼料を組成により，脂肪合成型と脂 肪分解型に区別しうるとした。そして, YosHIDA et al. ${ }^{23)}$ は脂肪分解型飼料により，成長中のヒナの体脂肪蓄積を 調節し, 初生ヒナと同様, 飼料中の可消化等分総量を $20 \%$ 下げることと，蛋白質含量を $9 \%$ 上げることとは， 同程度の脂肪分解効果を示し，しかも，而に独立である ことを報告した。しかし，YOSIDA and HoSHI24) 注座卵 鵎に対して, 飼料のエネルギ一含量は有効に作用する が，蛋白質含量の变化は，ヒナの場令とは対照的に，産 卵鶏の腹腔脂肪含量に対し影響しなかったことを明らか にし, 産卵鷄は, 蛋白質または脂肪の代㴬でヒナとは㾏 があること文示唆した。緒方ら 25) もまた，肉用種の産卵 䳕で, 蛋白質含量を高めても低めても, 腹腔内脂肪量の 増減はないものと推察している。そこで著者らは, 体脂 肪蓄栍におよぼす飼料蚠白質の影響について, 成辰中の

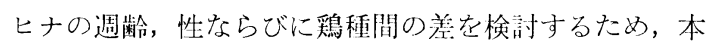
実験を行なった。

\section{材料および方法}

供試ヒナは, 市販の白色レグホーン種（以下白レグと 昭和 48 年 4 月 16 日受付
略称一る) と肉用種（白色口ック種×白色コーニッシュ 種）で，慨付時から農林省畜産試験場慣行の方法で充成 したものを，雌雄それぞれ 24 羽ずつ，各測定日の 25 日 前から, $20^{\circ} \mathrm{C}, 13$ 時間照明の調温飼青室に移し, 各試験 飼料每に雌雄それぞれ 3 羽0 2 区ずつ計 4 区をわりあ $\tau, 4$ 種類の飼料（粗蛋白質一可消化養分総量：16-73， 16-60，22-73，22-60) を立之，4，6，8，12，16 打上び 20 週齿令時にと殺解体し, 腹膑脂肪貍を测定した。しふ

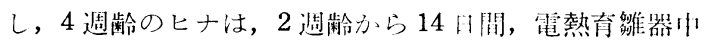
で飼養したものである。

䬲料組成は, YoshidA and HoshiI ${ }^{24}$ の使用したも0 と同じで，粗蛋白質と代㴬工六ルギーについては実測し た。

飼料撰取量牥，試験終了時に区每の飼料消費量を測分 し，1羽当りの平均掑取量を求めた。

体脂肪率と腹腔脂肪率との間には，既報26)のように強 い相関が琹められるので, 腹腔脂肪率によって脂肪の萻 積を比較検討した。なお，腹腔脂肪量の測定方法注同報 告26) と同様に行なった。

測定した腹腔脂肪率について, 性, 飼料蛋白質含量, 飼料エネルギー含星子よび卧齿令の影響を，分散分析法に より検討した。

結果

供試飼料について，粗蛋白質含量（\%)と代謝エネル ギー（ $\mathrm{kcal} / \mathrm{g} ）$ を測定したところ，4種の飼料はそれで れ，14.8-3.00，14.9-2.52,20.4-2.97, 20.2-2.47 の佔 を示した。粗蛋白質含量が滆算值より低かったのは，配 合原料の大豆粕と魯粉の粗蛋白質含量が，YOSHIDA and HosHII ${ }^{24)}$ の使用したものより低かったものと思われる。

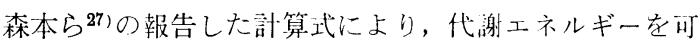
消化意分総量に換算したところ, 粗蛋白質一可消化養分 総量は，それぞれ，14.8-72.5，14.9-60.9，20.4-71.6， 20.2-59.6 となった。

各週歯合に測定した平均飼料撕取量の成績は，白レグ については表 1 に, 肉用種については表 2 にそれぞれ示 した。両鵎種とも 6 週齿令までの幼龄期には, 高蛋白質レ ベルのうが多く, その後の週齢では, 大体に抏いて低工 


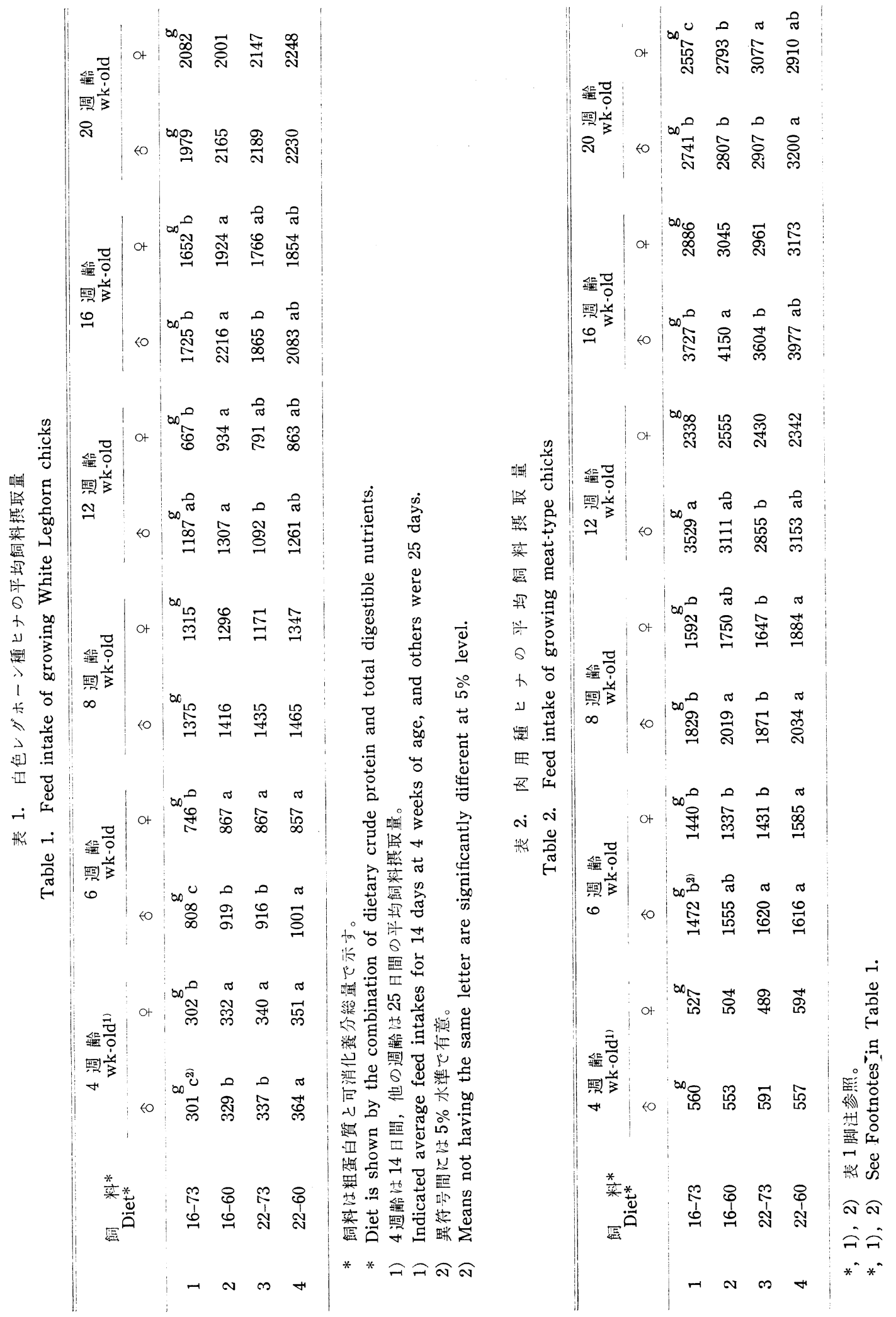



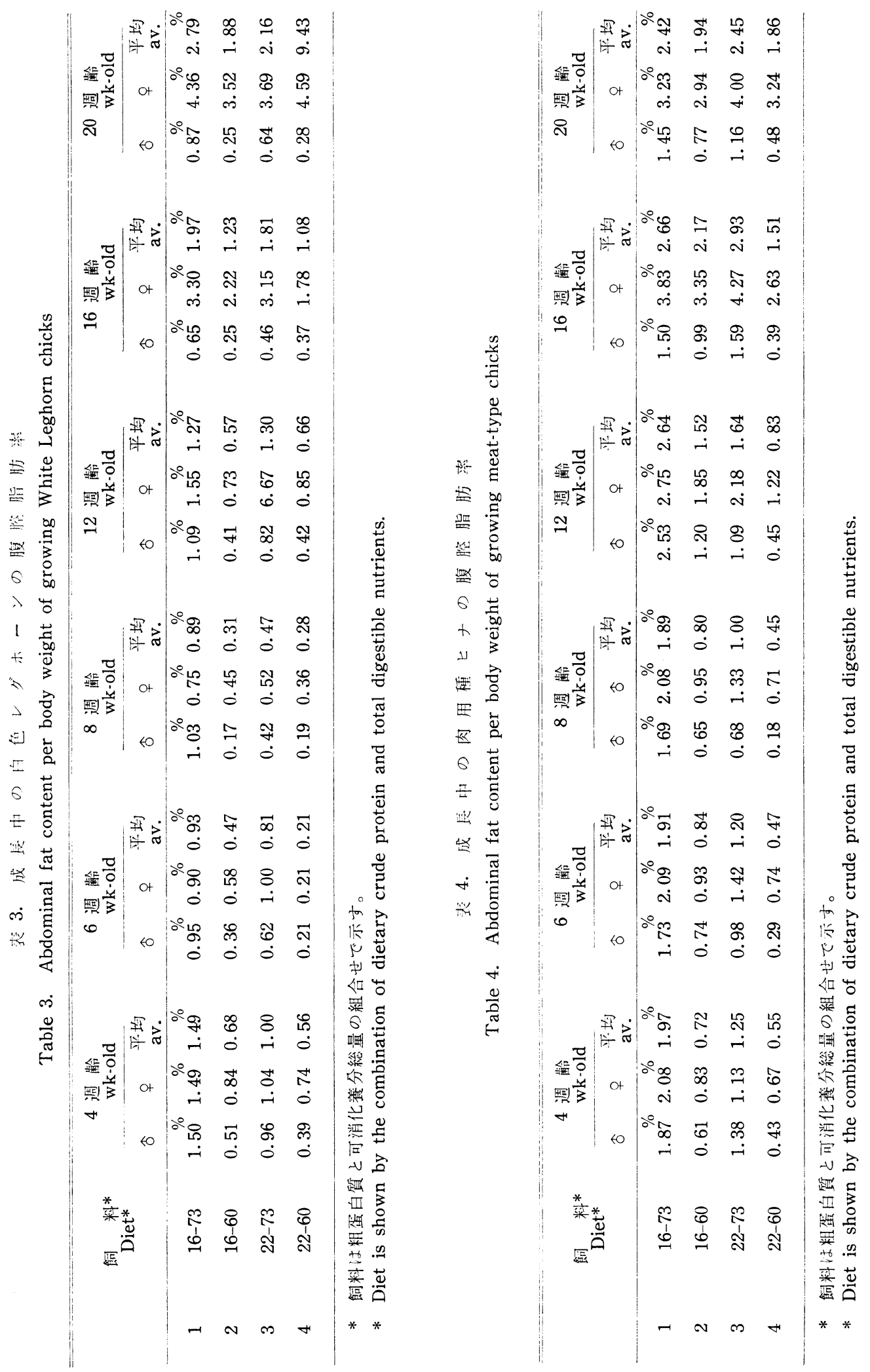


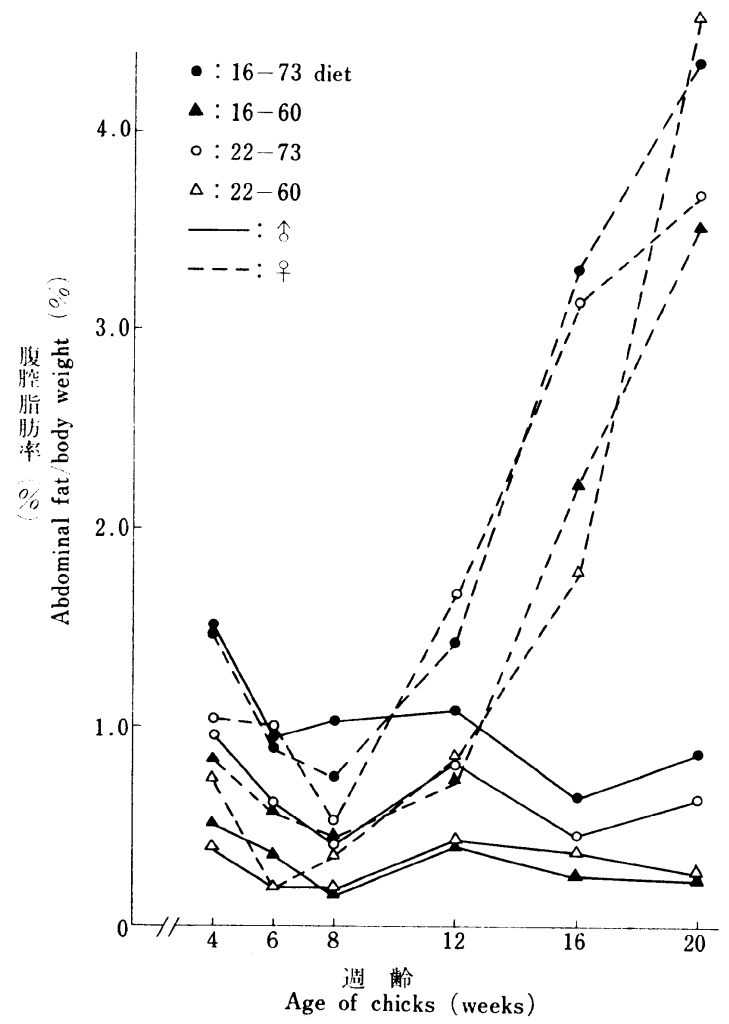

区1. 白色レグホーンの雌雄の飼料別腹腔脂肪率:

Fig. 1. Abdominal fat content of both sexes of growing White Leghorn chicks fed each experimental diet

ネルギーレバルの方を多く提取する傾问を示した。

腹腔脂肪率の週齢毎の成績は，白レグの場合を表 3 お 上び図 1 に，肉用種の場含在表 4 むよび垦 2 に，それぞ れ率した。

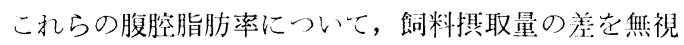
し, 養分含量にもとづき, 性, 飼料蛋白質, 飼料エネル

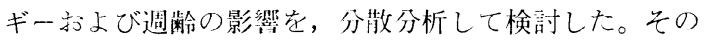
結果梳 5 に示した。

表 5 において, 主要因すべてに有意性が示されたが, 週歯と他の要因間の交市作用ずでてが, 両方もしく法 ナうの鶏種に才いて有意となっている。これは，週齢によ って他の要因の影響が変化することを意味し, 速歯令再に 分散分析して検讨与ざきであることを示した。

なお，肉用種に打いて，性と蛋白質の交互作用が份意 に忍められたのは，20週齢の雌の脂肪蓄積量が高蛋白質 レベルで著しく多くなったためである。

各週齢毎に, 性, 蛋白質掞よびエネルギーの影響を, 3 元配置法により分散分析したところ，白レグについて は表 6 に, 肉用種については表 7 にそれぞれ示す結果

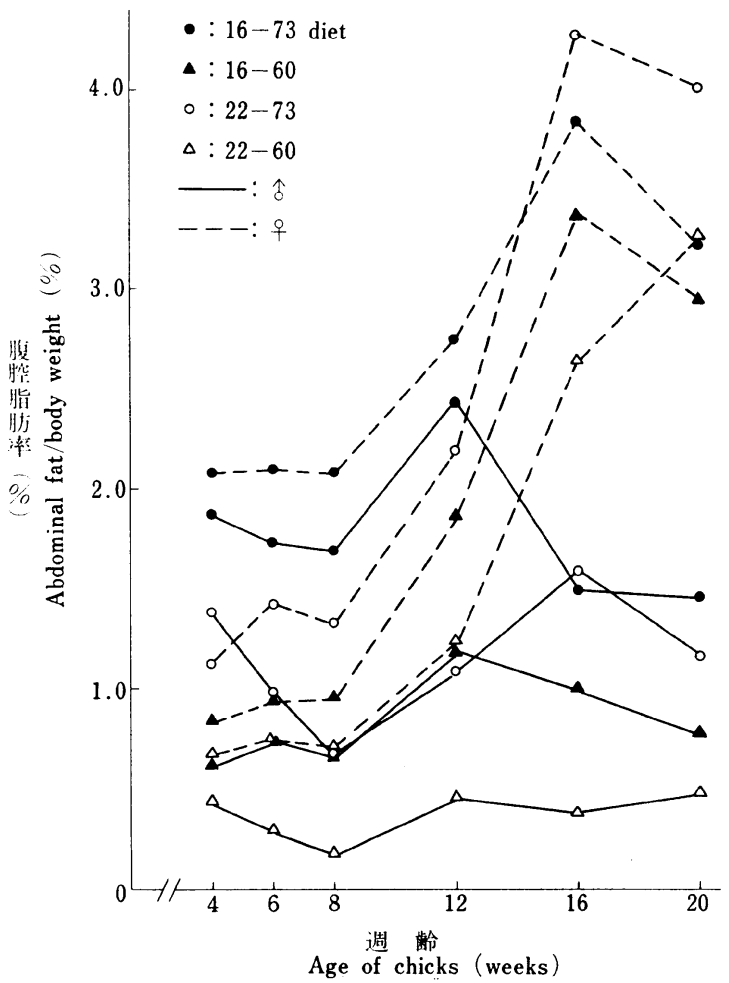

図2. 肉用種の雌雄の飼料別腹腔脂肪率

Fig. 2. Abdominal fat content of both sexes of growing meat-type chicks fed each experimental diet

えた。この両表からわかるように，性による脂肪率の差 は, 白レグで 6 と 8 週齢に, 肉用種では 4 週龄において 有意性が贸めら机なった。しかし，その他のすべての 週龄では，雌の脂肪率が有意に高くなった。蛋白質の影 響は，白レグは 4 と 8 週龄で有意であり，12 週歯令以後有 意ではなくなった。しかし肉用種では 12 週龄まで有意 であり，16と 20 週歯で有意でなくなっている。エネル ギーの影響について見ると，白レグでは 20 週龄は有意 でなかったが，その他の週龄で，また肉用種は全週歯令で 有意性が認められている。

交互作用は，日レグの 16 週龄に，性とエネルギー間 に涩められている。これは, 此雄とも高エネルギーの方 い脂肪率が高いが, 雌の才うの脂肪率が著しく高いので, 高低両エネルギー閒の差が大きくなり, 交百作用として 有意になったものである。

蛋白質とエネルギー間の交互作用は，白レグの 4 週歯令 と 20 週歯に，また肉用種の $4,6,8$ および 16 週歯にそ れぞれ楒められている。このうち, 白レグの 4 週歯と, 肉用種の 4,6 扎よ゙゙ 8 週齢は，ともに高エネルギー条 
表 5. 白色レグホーンと肉用種ヒナの経時的 腹腔脂肪率の分散分析

Table 5. Variance analyses of abdominal fat of growing White Leghorn and meat-type chicks

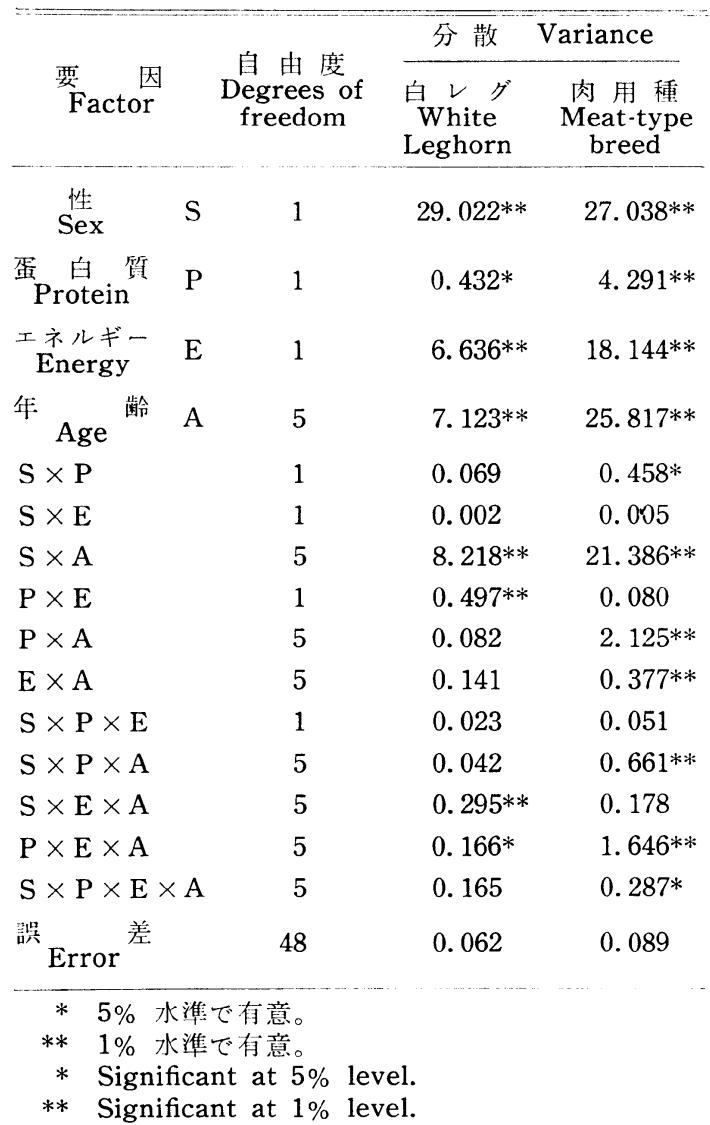

件下でのみか，あるい滈エネルギー条件下の少がより 強く，蛋白質の影響を赤しているものである。また，日 レグの 20 週㱓令と肉用種の 16 週歯浪は，低エネルギー条件 下でのタ有意であって，白レグは高蛋白質飼料凶の脂肪 率が高くなり，肉用種泜低蛋白質飼料区の脂肪率が高く 没ったものである。

考察

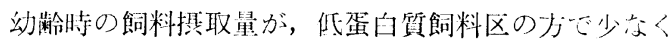
なったのは，給与を開始した 2 週龄ヒナにとって，粗蛋 白質含量 $14.8 \%$ では，やや低過ぎたためである上思わ れる。これは，飼得標準28 から考えても当然のここであ るが，産卵鶏まで同一組成の飼料を用いる実験計画のた め，やむをえないものであった。なお，その後の週龄で 注，エネルギーレベルの低い方が寒取㻎は多くなり， HILL and DANSKY ${ }^{4)}$ の発表以来一般によく知られている 現象と一致した結果を示した。

しかしながらこのように飼料掑取量に差があること は, 脂肪蓄積に関係与る蛋白質およびエネルギー摂取量 に差を生じ，本実験の結果の解釈を不正確にする恐れが あるし, YosHIDA et al. 21 23) の脂肪蓄積効果の一連の研 究も，幼齢ヒナの提取量が，ほぼ一定で大差がないこと に基いて行われているので，本実験のように摄取量に㾏 がある場合には，その影響を無視してよいかどうか疑問 となる。そこで，各週歯每の平均捸取量を各飼料区の提 取量で割った比率を，表 3 および 4 の腹腔脂肪率にかけ て修正脂肪率を求めてみた。

修正した腹腔脂肪率に基いて分散分析した結果，变っ た点を検討すると，まず，白レグの 6 週齢で，蛋白質の

表 6. 成長中の白色レグホーンヒナの腹腔脂肪率の分散分析

Table 6. Variance analyses of abdominal fat of growing White Leghorn chicks

\begin{tabular}{|c|c|c|c|c|c|c|c|c|}
\hline \multirow{2}{*}{ Factor } & \multirow{2}{*}{ 因 } & \multirow{2}{*}{$\begin{array}{l}\text { 自由度 } \\
\text { Degrees of } \\
\text { freedom }\end{array}$} & \multicolumn{3}{|r|}{ 分 散 } & \multicolumn{3}{|l|}{ Variance } \\
\hline & & & $\begin{array}{l}4 \text { 週 齢 } \\
\text { wk-old }\end{array}$ & $\begin{array}{l}6 \text { 週 齡 } \\
\text { wk-old }\end{array}$ & $\begin{array}{l}8 \text { 週 齢 } \\
\text { wk-old }\end{array}$ & $12 \begin{array}{l}\text { 週 歯令 } \\
\text { wk-old }\end{array}$ & $\begin{array}{l}16 \text { 週 齢 } \\
\text { wk-old }\end{array}$ & $\begin{array}{l}20 \text { 週 齢 } \\
\text { wk-old }\end{array}$ \\
\hline $\begin{array}{l}\text { 性 } \\
\text { Sex }\end{array}$ & S & 1 & $0.140^{*}$ & 0.078 & 0.021 & $0.949 * *$ & $19.018 * *$ & $49.907 * *$ \\
\hline 蛋 白 質 & $\mathrm{P}$ & 1 & $0.374^{* *}$ & 0.146 & $0.210^{*}$ & 0.002 & 0.100 & 0.012 \\
\hline $\begin{array}{c}\text { エネルギー } \\
\text { Energy }\end{array}$ & $\mathrm{E}$ & 1 & $1.571 * *$ & $1.114 * *$ & $0.589 * *$ & 1. $698 * *$ & 2. $157 * *$ & 0.213 \\
\hline $\mathrm{S} \times \mathrm{P}$ & & 1 & 0.003 & 0.012 & 0.019 & 0.091 & 0.067 & 0.091 \\
\hline $\mathrm{S} \times \mathrm{E}$ & & 1 & 0.089 & 0.003 & 0.098 & 0.050 & $0.961^{*}$ & 0.276 \\
\hline$P \times E$ & & 1 & $0.145^{*}$ & 0.021 & 0.147 & 0.009 & 0.0002 & $1.003^{*}$ \\
\hline $\mathrm{S} \times \mathrm{P} \times \mathrm{E}$ & & 1 & 0.001 & 0.105 & 0.060 & 0.040 & 0.092 & 0.547 \\
\hline Error & & 8 & 0.023 & 0.034 & 0.028 & 0.072 & 0.111 & 0.107 \\
\hline
\end{tabular}

* $5 \%$ 水準で有意, ** $1 \%$ 水準で有意。

* Significant at $5 \%$ level, ** significant at $1 \%$ level. 
表 7. 成長中の肉用種ヒナの腹腔脂肪率の分散分析

Table 7. Variance analyses of abdominal fat of growing meat-type chicks

\begin{tabular}{|c|c|c|c|c|c|c|c|c|}
\hline \multirow{2}{*}{ Factor } & \multirow{2}{*}{ 因 } & \multirow{2}{*}{$\begin{array}{l}\text { 自由度 } \\
\text { Degrees of } \\
\text { freedom }\end{array}$} & \multicolumn{3}{|r|}{ 分 散 } & \multicolumn{2}{|l|}{ Variance } & \multirow[b]{2}{*}{$\begin{array}{l}20 \text { 週 齢 } \\
\text { wk-old }\end{array}$} \\
\hline & & & 4 週 齢 & $\begin{array}{l}6 \text { 週 齢 } \\
\text { wk-old }\end{array}$ & 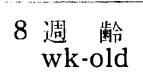 & $\begin{array}{l}12 \text { 週 齢 } \\
\text { wk-old }\end{array}$ & $\begin{array}{l}16 \text { 週 齢 } \\
\text { wk-old }\end{array}$ & \\
\hline $\begin{array}{l}\text { 性 } \\
\text { Sex }\end{array}$ & S & 1 & 0.043 & $0.435 * *$ & $0.874^{* *}$ & $1.869 * *$ & $23.095^{* *}$ & $22.008^{* *}$ \\
\hline 蛋 旨 質 & $\mathrm{P}$ & 1 & $0.781 * *$ & $0.906 * *$ & $1.541 * *$ & $2.853 * *$ & 0.152 & 0.026 \\
\hline $\begin{array}{c}\text { エネルギー } \\
\text { Energy }\end{array}$ & $\mathrm{E}$ & 1 & $3.829 * *$ & $3.413^{* *}$ & $2.697 * *$ & $3.686 * *$ & 3. $661 * *$ & $1.521^{*}$ \\
\hline $\mathrm{S} \times \mathrm{P}$ & & 1 & 0.047 & 0.058 & 0.059 & 0.249 & 0.013 & 0.722 \\
\hline $\mathrm{S} \times \mathrm{E}$ & & 1 & 0.064 & 0.021 & 0.010 & 0.004 & 0.043 & 0.056 \\
\hline $\mathrm{P} \times \mathrm{E}$ & & 1 & $0.311^{*}$ & $0.213^{*}$ & $0.285^{*}$ & 0.097 & $0.860^{*}$ & 0.027 \\
\hline $\mathrm{S} \times \mathrm{P} \times \mathrm{E}$ & & 1 & 0.057 & 0.029 & 0.0001 & 0.002 & 0.057 & 0.069 \\
\hline 䛊 ${ }^{\text {Error }}{ }^{\text {差 }}$ & & 8 & 0.036 & 0.023 & 0.052 & 0.144 & 0.132 & 0.164 \\
\hline
\end{tabular}

* 5\%水準で有意，** 1\%水準で有意。

* Significant at $5 \%$ level, ** significant at $1 \%$ level.

脂肪蓄積抑制効果が有堵に認められるようになった。こ れは，低蛋白質区の飼料掑取量が最大值に比ぶて $20 \%$ も少ない区があり，低蛋白質による体脂肪の蓄積堌加 が，見掛上打消されていたことを示している。また，白 レグの 4 週齢では, 統計的に注最低限度の有意性で綕め ら机ていた性の差が，僅かな補正により有意でなくなっ ただけに過ぎなかった。

白レグのその他の週齢と，ブロイラーの全週歯令では， 掑取量の補正により結諭は変らなかった。このことは, 表 1 および表 2 に示された程度の摂取量の差では, 飼料 組成による脂肪蓄積反忘を，覆兄与程の影響を与え得な かったものと判断しうる。事炎，本実験に供試した飼料 は提取量の差の影響を無視できるように, 予め, 粗蛋白 質やエネルギーの差を大きく設定してあるので，幼龄時

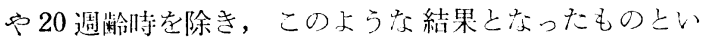
方る。

性による脂肪率の差：此雄間で脂肪蓄積に善のあるこ と法, DANSKY and HILL ${ }^{3)}$ の研究以来良く知られている が，本実験に打いても，供試飼料之関係なく，雌の方が 雄よりも高い脂肪率を示した。白レグでは，表6に示さ れているように，4週龄で性に有意差が恋められている が，前述したように，撰取量の補正によった 8 週歯まで は，統計的に澺とい有意なくなったが，䧳の少が多 い。したがって，白レグは 12 週以後において雌雄間で 脂肪率の有意差を赤生ようになることが恋められた。と ころが，肉用種は，表 7 に示すように，6週龄から有意 な差を示した。此雄毎に全飼料区の平均腹腔脂肪率を求 め, 図 3 に示した。この図でも明らかなように，両鷄種

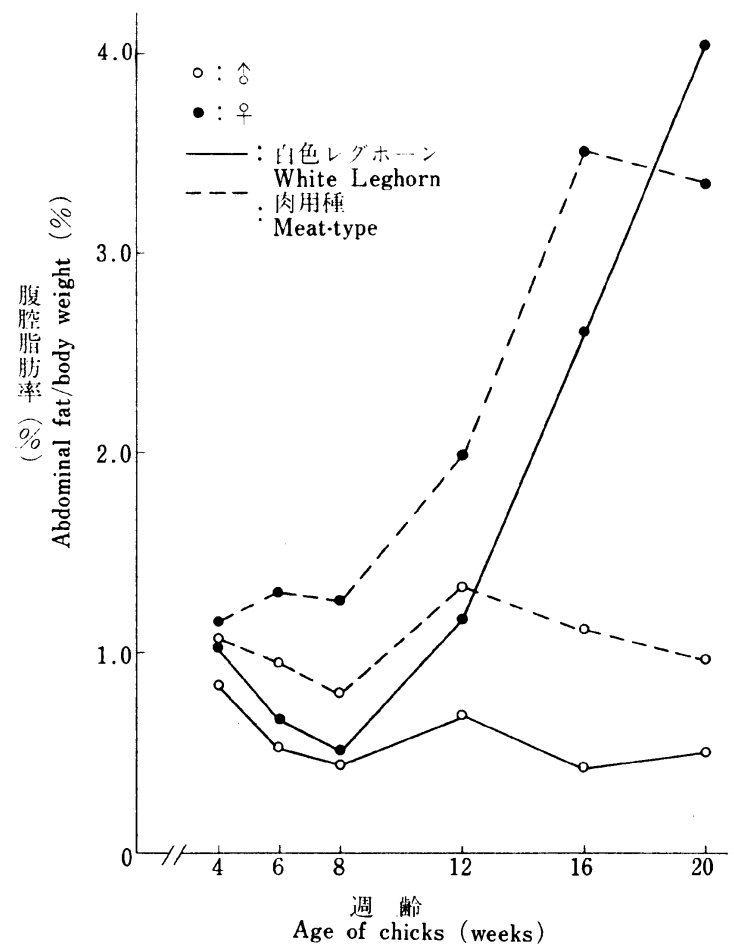

図 3. 白色レグホーンと肉用種の性別腹腔脂肪染

Fig. 3. Abdominal fat content of both sexes of White Leghorn and meat-type chicks

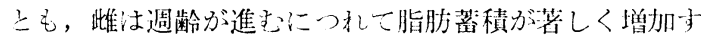
るが，雄の脂肪率は殆えど横谓いの状態を示している。 また，肉用種の方が白レグよりも脂肪率が高いことが贸 


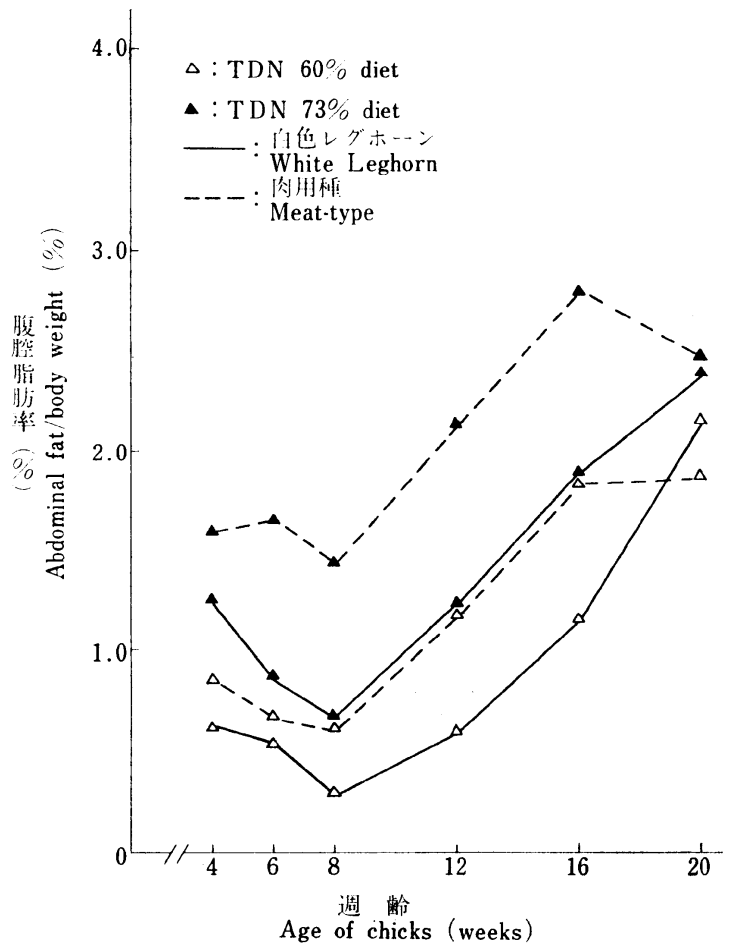

脳4. 白色レグホーンと肉用種のエネルギー 水準別腹腔脂肪率

Fig. 4. Abdominal fat content of White Leghorn and meat-type chicks at different energy levels

わら机る。このような現象は, 恐らく生理的な差異, 特 にホルモンの影響によるものと思われる。

エネルギーの影響：両鵎種とも，雌雄とれぞれエネル ギーレバルに応じて, 脂肪の蓄積を示していることは, 図 1,2 打よび 4 で明らかである。しかし, 白レグの 20 週 龄では, 図1でもわかるように, 高蛋白質低エネルギー (22-60) 区の雌が，著しい脂肪増加を示して最高となる 特筫な現象を示している。また, 肉用種でも, 図 2 に示 したように，20週歯の䧳の高蛋白質低エネルギー区が， 他の 3 区の脂肪率は 16 週龄に比べて減少しているのに 対して，逆に増加を示した。

両鷄種とも高蛋白質低エネルギー飼料の椇取量は, 他 の飼料より多いけ机ども，掑取量を補正した分析結果で も有意性に变りはなく, 単に, 損取量がやや多いという 理由だけで脂肪率の著しい増加を示したのではなく，む しろ, 性成熟期特有の反応が關係していること老示晙し ているものと思われる。

蛋白質の影響: 表 6 において, 白レグの 6 週欮に有意 性が涩められなかったが，前述したように，6週藏令の飼 料掑取量の差が特に大きかったので，掑取量を補正する

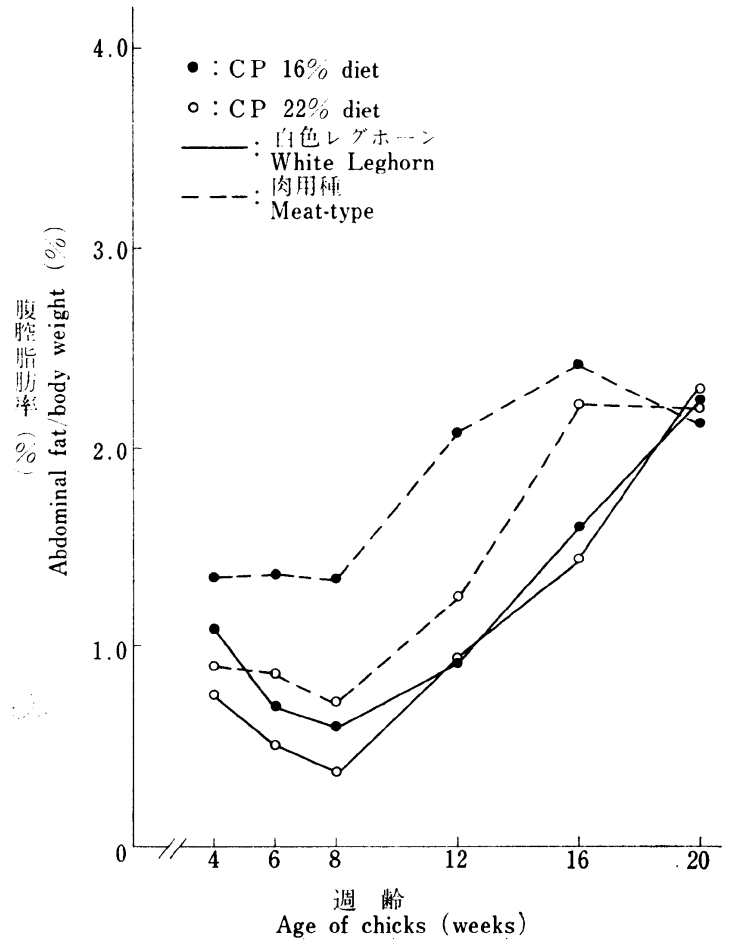

図 5. 白色レグホーンと肉用種の蛋白質水準別 腹腔脂肪率

Fig. 5. Abdominal fat content of White Leghorn and meat-type chicks at different protein levels

と, 蛋白質による脂肪染の差が有意といえた。このこと

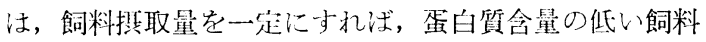
を与えると，脂肪の蓄積が增与ことを示焧与るものであ る。しふがって, 白レグでは 8 週邺まで, 蛋白質の効果 があり，12週龄で涩められないことが明らかとなった。

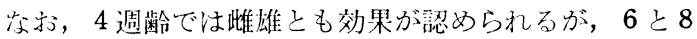
週龄では，雄だけ有意となり，此倠の方が早く效果が消失 するようである。

一方，肉用種に扔いては，表７扮よび図５で明らかな ように, 12 週齢まで蛋白钼の影響が認められ，白レグよ

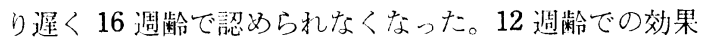
は，雄で明確に示されたが，此ではその差は少なく，白 レグと同槉，此のナが早く効果が贸められ衣くなるよう である。

このように，飼料中心）蛋白質による体脂肪蓄積の抑制 效果が, 白レグでは 8 から 12 週龄の間で, 肉用種では

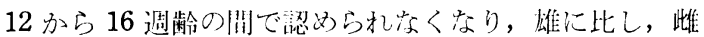
の方が早く抑制效果が認められなくなるといら以上の知 見は，飼料蛋白質の体脂肪蓄積抑制効果が，性ホルモン と閂連していることを示唆しているものとみなされる。 
以上の様に，本実験においては，供試飼料の実測值が 計算值よりやや低かったけれども，よく飼料蛋白質の脂 肪抑制効果を示した。大勢注図 5 によっても良くわかる が，詳細には，眓 1 および図 2 によって理解できる。特 に図 2 の肉用種では，最も良く反応した形で示されてお り，16-60 飼料区と 22-73 飼料区が，中間に位置する脂 肪率を示して展開している。この供試飼料の粗蛋白含量 の差は，実測值で約 $5.5 \%$ であり，代賭エネルギーの差 法約 $0.5 \mathrm{kcal} / \mathrm{g}$ であったのでこの両者が同程度の脂 肪蓄積抑制効果を示したことになる。これは， $1 \mathrm{~g}$ の飼 料蛋白質法， $-9.09 \mathrm{kcal} の$ 代謝エネルギーに匹敵する ことになり，Yoshida et al. ${ }^{23)}$ により報告された -9.44 $\mathrm{kcal}$ に近似の值となった。また，前述のように，可消 化湌分総量に換算した值で示すと，粗蛋白質 $5.5 \%$ と可 消化養分総量 $12 \%$ となり，同報告による $9 \%$ と $20 \%$ の 関係と同じ比率を亦していた。

\section{要約}

初生ヒナ犬゙成赵中の肉用種ヒナでは, 飼料蛋白質含量 の変化によって，体脂肪蓄積量が容易に影響を受ける が21 23)，産㖄鶏においては，蛋白質の影響がないことが 報告 ${ }^{24,25)}$ されているので, 成長中のヒナについて, 性, 週齒および鶏種間の差を検討した。

ヒナは市販の白レグと肉用種の此雄 576 羽を用い, 粗 蛋白質 $16 \%$ または $22 \%$ ，可消化養分総量 $60 \%$ または $73 \%$ を組合せた 4 種類の飼料を，と殺前， 4 週歯令七ナは 14 日間，その他のヒナは 25 日間与えて調温飼育室で飼 黨し，4，6，8，12，16 および 20 週龄時にと殺し，腹 腔脂肪率老測走した。

分散分析により検討したところ，次の結果をえた。

1） 20 遠龄の此以外のすべてで，高エネルギーの方が 脂肪蓄積は多く, 20 週歯令の雌は, 高蛋白質低エネルギー 飼料区の脂肪蓄積が顕著に増加し, 性成熟期との関連性 が示唆された。

2）飼料中の蛋白質による脂肪蓄積の抑制効果は，白 レグでは 8 から 12 週歯までの間で，肉用種では 12 から 16 週歯までの閒で，それぞれ認められなくなった。ま た，高蛋白質レベルの効果が雄よりも雌の方で早く涊め られなくなることから, 飼料蛋白質の効果が性ホルモン と関連していること羊唆しているのではないかとみな される。

3）供試飼料の実測值では，蛋白質レベルの差は約 $5.5 \%$ となり，代謝エネルギーの差は約 $0.5 \mathrm{kcal} / \mathrm{g}$ と なって，脂肪蓄積および抑制効果がよく一致していた。 したがって，1 g の飼料蛋白質は， $-9.09 \mathrm{kcal} の$ 代謝 エネルギーにほぼ匹敵した効果を示した。
4）白レグの 6 週齢以外のすべての週龄で, 飼料提取 量を補正しても, 蛋白質の脂肪蓄積抑制効果に变化はな く，本実験での供試飼料は，幼週歯期を除き，提取量の 差を無視できるものであった。

\section{文献}

1) FRAPS, G.S.: Poultry Sci., 22, 421, 1943.

2) Scott, H. M., L. D. Matterson and E. P. SingSEN: ibid., 26, 554, 1947.

3) Dansky, L.M. and F.W. Hill: ibid., 31, 912 , 1952.

4) Hill, F.W. and L.M. DANSKY: ibid., 33, 112, 1954.

5) Cомвs, G.F. and E.J. Robel: ibid., 41, 1636, 1962.

6) Donaldson, W.E., G.F. Combs, G.L. Romoser and W.C. SuPPLEE: ibid., 34, 1190, 1955.

7) Leong, K.C., M.L. Sunde, H.R. Bird aud C.A. Elvehjem: ibid., 34, 1206, 1955.

8) Leong, K.C., M.L. Sunde, H.R. Bird and C.A. ElvehJem: ibid., 38, 1267, 1959.

9) Donaldson, W. E., G. F. Combs and G. L. ROMOSER: ibid., 35, 1100, 1956.

10) Williams, M.A. and C.R. Grau: J. Nutr., 59, $255,1956$.

11) Vondell, R.M. and R.C. Ringrose: Poultry Sci., 37, 147, 1958.

12) Rand, N.T., F.A. Kummerow and H.M. Scott: ibid., 36, 1151, 1957.

13) SPring, J.L. and W.S. Wilkinson: ibid., 36 1159, 1957.

14) Biely, J. and B. MARCh: ibid., 36, 1235, 1957.

15) Yoshida, M., S. Hizikuro, H. Hoshil and H. Morimoto: Agr. Biol. Chem., 26, 640, 1962.

16) Combs, G.F.. E.H. Bossard, G.R. Childs and D.L. Bla mberg: Poultry Sci., 43, 1309, 1964.

17) Essary, E.O. and L.E. Dawson: ibid., 44, 7, 1965.

18) Summers, J.D., S.J. Slinger and G.C. Ashton: ibid., 44, 501, 1965.

19) Rajaguru, R.W.A.S.B., P. Vohra and F.H. Kratzer: ibid., 45, 1339, 1966.

20) Shank, F.R., O.P. Thomas and G.F. Combs: ibid., 47, 1718, 1968.

21) Yoshida, M. and H. Morimoto: Agr. Biol. Chem., 34, 414, 1970.

22) Yoshida, M. and H. Morimoto: ibid., 34, 423, 1970.

23) Yoshida, M., H. Hoshil and H. Morimoto: Japan. Poultry Sci., 7, 166, 1970.

24) Yoshida, M. and H. Hoshil: ibid, 9, 115, 1972.

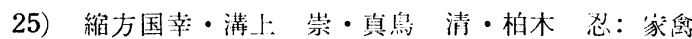
会誌，9，46，1972.

26）重野堂吉：家禽会誌，10，春季大会号，29, 1973.

27）森本 宏・滗田大作・有吉修二郎・土黑定信：農 技研報 $\mathrm{G}, 20,157,1961$.

28）森本 㕕：家畜栄養学，養賢堂，東京，1969。 


\title{
Age and Breed Difference in the Effect of Dietary Protein on Carcass Fat Deposition of the Chicken
}

\author{
Kakichi Shigeno, Hiroshi Hoshir* and Minoru Yoshida* \\ Faculty of Agriculture, Gifu University, Kagamigahara-shi \\ * National Institute of Animal Industry, Chiba-shi
}

It has been reported that starting chicks and growing meat-type chicks can easily become fatty or lean by simply changing dietary levels of protein, but, in striking contrast, dietary protein levels have little effect on abdominal fat content of laying hens. In this paper, is reported the effect of dietary levels of energy and protein on the body fat deposition of growing chicks of both sexes of two strains at various ages.

Both males and females of White Leghorn or meat-type cross-breds were sacrificed at $4,6,8,12,16$ and 20 weeks of age for abdominal fat determination. Abdominal fat was determined because it has highly significant correlation with body fat deposition. Therefore, the latter can be estimated from the former. Except those sacrificed at 4 and 6 weeks of age, 24 males and 24 females were moved from the farm of National Institute of Animal Industry into the chick room kept at constant temperature of $20^{\circ} \mathrm{C}$., and divided into 16 groups of 3 chicks each. One of the 4 experimental diets was fed to duplicated lots of males and females for 25 days before the determination of abdominal fat. Two-week-old chicks were reared in an electrically heated battery brooder for 2 weeks in the chick room on the experimental diets and sacrificed at 4 and 6 weeks of age as mentioned above.

The combination of 2 levels of crude protein and 2 levels of metabolizable energy (kcal/g air-dry diet) prepared 4 experimental diets. Their contents were determined to be $14.8 \%-3.00 \mathrm{kcal} / \mathrm{g}, 14.9 \%-2.52 \mathrm{kcal} / \mathrm{g}, 20.4 \%-2.97 \mathrm{kcal} / \mathrm{g}$ and $20.2 \%-2.47 \mathrm{kcal} / \mathrm{g}$, respectively.

Effect of dietary energy and protein levels on abdominal fat deposition was analyzed statistically at various ages, and following results are obtained:

1) Higher dietary energy level resulted in more deposition of abdominal fat in all stages of growth, except females at 20 weeks of age. Females at 20 weeks of age deposited large amount of abdominal fat even on low energy-high protein diet, presumably related with the sexual maturity of females.

2) Higher level of dietary protein depressed fat deposition of White Leghorn chicks of both sexes at 8 weeks or younger and of meat-type chicks of both sexes at 12 weeks or younger. Little difference in abdominal fat deposition was observed between the chicks older than mentioned above, fed either high or low protein diets. It was also observed that the effect of high protein diet on fat deposition disappeared earlier in females than in males. These findings suggest that the depressing effect of dietary protein on fat deposition is related with sex hormones. 
3) In young chicks, on which the depressing effect of dietary protein on fat deposition was seen, the increase in dietary protein level by $5.5 \%$ approximately corresponded to the decrease in dietary metabolizable energy by $0.5 \mathrm{kcal} / \mathrm{g}$, in other words, one $\mathrm{g}$ of dietary protein apparently corresponded to $-9.09(=0.5 / 0.055) \mathrm{kcal}$ of metabolizable energy, which closely resembles to $-9.44 \mathrm{kcal}$ reported previously.

4) Body fat deposition is related to actual intake of energy and protein rather than to their dietary content. However, it was revealed that change in feed intake under the experimental condition was so small that it was negligible in the discussion on fat deposition, except the change in feed intake of young White Leghorn chicks at 6 weeks of age. Dietary protein level of $14.5 \%$ seemed to be too low for young chicks and feed intake of the low protein diet was less than that of the corresponding high protein diet. This difference in feed intake had influence on fat deposition.

(Japan. Poultry Sci., 10, 197 206, 1973) 